\title{
Socio-cultural Constraints of Girls' Access to Education in Mtwara District, Tanzania
}

\author{
Neema Silas Mollel \\ University of Science and Technology of China (USTC), China \\ Ren Chong \\ University of Science and Technology of China (USTC), China
}

\section{Introduction}

Education is a very crucial tool that gives an individual identity and prepares $\mathrm{him} /$ her with the related skills and knowledge which enables him/her to solve the different challenges that s/he may face everyday life in general. Education assists a person to be productive in various aspects of life (Zombwe 2010). Education helps to create awareness to girls about their rights and give them confidence and empower them to achieve human rights that denied to them. Girls' education has also verified to be an amazingly effective promoter for social development and economic growth in developing countries. Thus it makes some sense that educating the girl is to empower the broader society (UNICEF 2007). Though its significant girls lag behind it, worldwide, while the numbers of children out of school have been lessening since 2005; girls comprise a small proportion compared to boys. In general, around 28 million boys and 30 million girls who are supposed to be at primary school by their age are out of school, worldwide. Conversely, there are differences according to regions. There is also a big difference in out of school rates if compare girls and boys of secondary education age across regions, only a few girls have the opportunity to continue with secondary education (Katie 2015).

The condition is worse in Africa as a low development continent it remains behind the rest of the world's continents in girls' education. Most African girls are not given the right to education. Girls' inability to recognize their education right has profound effects on their capability to recognize their other social, political and economic rights (Gibson 2004). Hence, it makes them be humiliated and become the most vulnerable group in the community. Opportunities to go through secondary education are insufficient to many girls in Africa continent. Whereby in most African countries smaller number of girls than boys get the chance to continue with their studies in secondary education and the gap between girls and boys in enrollment continue to increase as the level of education becoming higher, 
very few girls get the opportunity to reach higher education (DFID 2006). After around fourteen years of age, most girls are less expected to be in school than boys. Many reasons make them being out of school including cultural beliefs and customs, marriage at an early age and early pregnancy which are among the key factors for gender inequalities in enrolment and accomplishment. The level of education that mostly attained by the majority of girls for both rural and urban locations is a basic education (primary level education) (USAID 2013). However, $55 \%$ of the 31 million girls out of school are expected never even to be enrolled. The situation is significantly worse in the Arab States and Sub-Saharan Africa, whereby it projected that among three girls out of school two of them are expected never to get a chance to be in school (UNESCO 2014).

Moreover, United Republic of Tanzania constitution based on equality in education at all levels regardless of gender, religion, and tribe. Hence give the opportunity for all people to acquire self-education as they can (URT 2005); still, the country suffers from gender inequality regarding access and success in girls' education. The problem of access to education opportunities has remained as a big problem among girls (Temba et al. 2013). The statistics indicate that the number of girls who complete different levels of education is deficient. In the post-primary level, girls' participation in education is significantly lower than that of boys. Gender parity indexes fall from 1.04 (whereby the number of girls' enrolment is greater than boys') in primary school to 0.65 at the higher/tertiary level of education. Similar data show that girls' enrolment in Technical and Vocational Education and Training is still low for girls, whereby boy students accounted for 55 percent of learners in 2008. The situation is essentially bad at the higher education level, girls' enrolment has barely reached 34 percent (UNESCO 2011). The percentage of girls completing a full secondary education was extremely low $0.8 \%$ in 2010 . Nearly 1.2 million teenage girls are out of school (GCE 2012). Repetition and dropout proportion are significantly higher to girls while completion rate is very low; also there is a strong gender inequality in providing education and performance in education between girls and boys (USAID 2013).

In Mtwara region education performance is very low, the region is among the bottom regions in education performance in Tanzania. Only 65 percent performed well in their standard four (IV) primary school examination while 35 percent needed to repeat the class and only 41 percent of students passed in their basic education; the Primary School Level Examination (PSLE) in 2007 (Basic Education Statistics in Tanzania (2004-2008) (USAID 2013). This shows that many students fail to continue to secondary education. Childbearing for adolescents is very high in Mtwara as statistics show that 35.5\% of adolescent had started childbearing in Mtwara compared to $26 \%$ countrywide as projected by the 
Tanzania National Bureau of Statistics (TNBS) in 2004 (Batho 2012). It estimated that up to 1 percent of primary school girls within the age of fertility become pregnant every year. Each year around 500 pregnancies reported from primary schools and about 100 from secondary schools in the Mtwara region (Kessler 2009)

Mtwara District also is suffering from girls drop out, whereby in 2005-2011; 15\% of the girls who supposed to complete basic education dropped out, in 2006-2012; 27\% dropped out, 2007-2013; 32\% dropped out, 2008-2014; 34\% dropped out, 2009-2015; 44\% dropped out. The same data show that many girls who are selecting to join secondary school do not report to school. In 2012; 43\% didn't report, 2013; 56\% didn't report, 2014; 61\% didn't report, 2015; 51\% didn't report (Mtwara District Education Office, 2016). The current worse situation of girls' education in Mtwara District that enforced the researcher to see important to understand better and with empirical evidence, the socio-cultural constraints of girls' access to education specifically in the District. The findings obtained from this study aims at assisting the education stakeholders to include policy makers, planners, government, non-government organizations in laying down a foundation that will possibly be used in changing the deteriorating situation of girls' education.

\section{Theoretical framework}

\subsection{Relevant theory}

This study based on Needs Hierarchy Theory developed by Abraham Maslow which consists five stages. Progression to higher stages of needs occurs through motivation. Once the lower stage needs encountered, the individual can progress to the next stage of needs. Every individual has an ability to reach the top stage need, and every person has an aspiration to achieve the highest stage need of selfactualization. Unfortunately, the movement is often interrupted by failure to encounter lower stage needs. Life experiences, including marriage at an early age and poverty, may cause an individual to swing between stages of the hierarchy. The first stage of need hierarchy is what Maslow called our greatest basic needs or "physiological needs": include food, water, shelter, sleep, air, etc. When humans deprived of these basic needs, they may find any alternative means to ensure that they obtain them as they are so crucial to life. This was true for the girls in the study area as many are engaged in small business activities due to lack of some basic needs at their homes which in turn impacts their education. The next stage in the hierarchy after meet that of the first is that of "safety needs": i.e. freedom from fear, security, protection, law, order, limits, etc. Unfortunately, many girls in the area of study sometimes lived in fear of forced and early marriage and other abuse. 
The third stage is that of social needs, love and belongingness needs, include acceptance, receiving and giving affection, companionship. The community tends to deprive girls of these significant needs. This is obviously happening because of the preferences that are given to the boy child from the family level to the community in general. Maslow's fourth stage is called "esteem needs" include achievement, independence, status, recognition, dominance, attention, prestige, self-respect and respect from others. People who get their needs fulfilled at this level are secure, confident, and stable. Maslow continues to argue that conversely, those who deprived of these needs creates feelings of inferiority, of weakness, and feelings of helplessness. Girls perform a great role in the society, but they are still not appreciated rather than undermined in the community. Low esteem of girls can affect their education. Girls who have a low self-esteem will have a low confidence and become unable to do well in their studies until their self-esteem is raised up. The last stage is "self-actualization need" include achieving personal potential, selffulfillment, seeking personal development and higher experiences. Girls fail to fulfill their goals since they lack motivation and supportive environment from the community. Bad cultural practices like early and forced marriage, male preference, etc. impede girls to achieve their goals. Maslow's theory is therefore applicable in this study because its emphasis and considerations based on the provisions of low stages need for one to achieve the higher needs. The theory is useful in illustrating the way deprive of needs to girls can affect their education. The theory is concerned with the achievement of self -actualization at the topmost of the pyramid in which education may be considered to be the key to achieving it. If the girls deprive of the low stages needs it will impact their opportunity of participation in education then their self- actualization is accordingly hindered. So the community should ensure the accomplishment of low stages needs to girls that will create the supportive environment for girls' education achievement and enable them to achieve their higher goals (self-actualization). 


\subsection{Conceptual framework}

\begin{tabular}{||l|l|l|}
\hline $\begin{array}{l}\text { Socio-cultural Factors } \\
\text { - Traditional ceremonies } \\
\text { - Male preference } \\
\text { - Early marriage }\end{array}$ & $\begin{array}{l}\text { Educational outcomes } \\
\text { - Dropout from school } \\
\text {-Poor academic performance } \\
\text { - Low value on girls' } \\
\text { education }\end{array}$ \\
\hline \hline $\begin{array}{l}\text { Social roles } \\
\text {-Gender based roles in } \\
\text { the community }\end{array}$ & $\begin{array}{r}\text {-Inequality } \\
\text {-Early pregnancies }\end{array}$ \\
\hline \hline $\begin{array}{l}\text { Social perception } \\
\text {-Community attitudes } \\
\text { towards girls' education }\end{array}$ & -Less time to study \\
\hline
\end{tabular}

Fig.1: Conceptual framework of socio-cultural constraints of girls' education Source: Researcher construct

The study shows the socio-cultural constraints of girls' access to education in Mtwara district, Tanzania. The study shows the socio-cultural constraints of girls' access to education in Mtwara district, Tanzania. In the conceptual framework depicted in Fig.1, the factors; socio-cultural (culture, social roles, social perception) affect the girls' participation in education. These factors result in many negative outcomes to girls education (dropout from school, poor academic performance, low value on girl's education, inequality, early pregnancies, lessening time to study) which at the end it affects the participation of girls' in education.

\section{Research Methodology}

\subsection{Research Design}

This study adopted a survey research design. Sasford, (2007) defines survey research as the collection of quantifiable data from a population for purposes of description of identifying verifications that may point to casual relationships. This design was applicable for the study because it captured people's opinions, beliefs, and attitudes about socio-cultural constraints to girl's access to education. The 
descriptive survey design is appropriate because it involves the collection of information, then assessing, finally, describing the data analysis regarding the constraints of girl's access to education within the shortest time possible.

\subsection{Sampling Procedures and Sample size}

Purposive and simple random sampling used to select the respondents. Purposive sampling used to choose the area of study (Mtwara District). Simple random sampling used to pick schools, teachers and girls' students in the selected schools for study. There is a total of 150 respondents in the study from five schools; 25 teachers, five from each selected school sample, and 125 girls' students from standard five, six and seven, 25 from each selected school sample. These grades have chosen as the researcher believe that in this grade children have enough understanding even concerning their cultures. The entire number of primary schools in the chosen study area are 67. The five schools selected by considering its distance, transport and time as the study area is rural area and schools are so separate. These schools will represent other schools in the study area as the culture, and other characteristics of the selected sample are the same since the whole study area primarily occupied by the people of the same tribe who shares the same culture and other characteristics.

\subsection{Data Collection Method}

The study applied close-ended questionnaire to gather the information from the targeted respondents and documentary review. The questionnaire developed from the research questions and review of the related literature and studies. In the closed-ended questionnaire, the respondents were specifically respond using tick $(\checkmark)$ for their answers. The closed-ended questionnaire is easy to manage because each item is followed by alternative answers and is inexpensive to use concerning duration. The researcher requested for ethical agreement with school principals and respondents. Then after, the researcher distributed the questionnaire to be filled. This took place during break time to avoid interference with the class timetable of students and also give the researcher the chance to have some informal discussion and interview with teachers and students as they are free at this time. Also, data from Mtwara District Education Office, about enrolment of girls and completion used as secondary data, whereby the researcher visited Mtwara District Education Office to get the data.

More than the questionnaire, researcher engaged in the informal interview with Native community members to understand in a detailed manner the factors that 
hinder girls' education in Mtwara District and neighboring villages in the district. A small number of old and experience people similarly interviewed for detailed explanations about the traditional and other issues concerning the local people.

\subsection{Data Analysis}

The data organized and then analyzed with the use of the computer. IBM SPSS software used. The design that adopted in this research is survey research design. Data presented in tables with emphasis to percentages then results reported by restating objectives on selected variable.

\section{Results and Discussions.}

The purpose of this research was to examine how socio-cultural factors become constraints on girls' access to education and suggest the ways toward refinement of the identified situation. Evidence from the study has shown that girls' access and success in education is very low in Mtwara District. As illustrated in Table 1, many girls drop out of school before completing their seven years of basic education. The situation is worse as years goes the percentage of girls drop out of school increasing rather than decreasing. The situation of girls' education proceeds to be worse not only in primary education but also in transition to secondary education.

Table 1: Basic education enrolment of girls, dropout rate and completion in Mtwara District

\begin{tabular}{|c|c|c|c|c|c|}
\hline $\begin{array}{c}\text { Year of } \\
\text { enrollment }\end{array}$ & $\begin{array}{c}\text { No. of } \\
\text { girls } \\
\text { enrolled }\end{array}$ & $\begin{array}{c}\text { Year of } \\
\text { school } \\
\text { completion }\end{array}$ & $\begin{array}{c}\text { No. of girls } \\
\text { who } \\
\text { completed } \\
\text { school }\end{array}$ & $\begin{array}{c}\text { No. of girls } \\
\text { who } \\
\text { dropped } \\
\text { out }\end{array}$ & $\begin{array}{c}\text { \% of girls } \\
\text { dropped } \\
\text { out }\end{array}$ \\
\hline 2005 & 3143 & 2011 & 2668 & 475 & 15 \\
\hline 2006 & 3202 & 2012 & 2333 & 869 & 27 \\
\hline 2007 & 3495 & 2013 & 2371 & 1124 & 32 \\
\hline 2008 & 4047 & 2014 & 2637 & 1410 & 34 \\
\hline 2009 & 3969 & 2015 & 2207 & 1762 & 44 \\
\hline Total & 17856 & & 12216 & 5640 & \\
\hline
\end{tabular}

Source: District Education Office

As presented in Table 2 despite many girls are dropped out of school in basic education, few complete and pass in their basic education examination (Primary School Level Examination (PSLE) hence selecting to continue with secondary education but many of them do not report to school to continue with secondary education. Socio-cultural factors associated with the low success of girls in their 
education. As the majority of respondents, $81.4 \%$ agreed that socio-cultural practices hinder the education of girls in the community.

Table 2: Mtwara District secondary school girls' enrolment

\begin{tabular}{|c|c|c|c|c|}
\hline $\begin{array}{c}\text { Year of } \\
\text { enrollment }\end{array}$ & $\begin{array}{c}\text { No. of girls } \\
\text { selected to join } \\
\text { form I (secondary } \\
\text { education) }\end{array}$ & $\begin{array}{c}\text { No. of girls } \\
\text { reported to } \\
\text { school }\end{array}$ & $\begin{array}{c}\text { No. of girls } \\
\text { who didn't } \\
\text { report to } \\
\text { school }\end{array}$ & $\begin{array}{c}\text { \% of girls } \\
\text { didn't report } \\
\text { to school }\end{array}$ \\
\hline 2012 & 1423 & 799 & 624 & 43 \\
\hline 2013 & 1257 & 544 & 713 & 56 \\
\hline 2014 & 1048 & 401 & 647 & 61 \\
\hline 2015 & 1732 & 846 & 886 & 51 \\
\hline Total & 5460 & 2590 & 2870 & \\
\hline
\end{tabular}

Source: District Education Office

Among the socio-cultural factors mentioned that hinder girl's education are early marriage; this seems to be very common in place and affects girls education as $86 \%$ of respondents agreed on that. Negative perception placed on girl's education by the community impacts girls' education as agreed by $73.3 \%$ of respondents; also traditional ceremonies (unyago) realized to have impacts on girls education as agreed by $68.7 \%$ of respondents. Social roles also have impacts on girls education it agreed by $67.3 \%$ and male preference as decided by $67.4 \%$ of respondents as shown in Table 3.

Table 3: Identified socio-cultural factors affecting girls education by percentages

\begin{tabular}{|l|c|c|c|c|}
\hline Variable & $\begin{array}{c}\text { Agree } \\
\%\end{array}$ & $\begin{array}{c}\text { Disagree } \\
\%\end{array}$ & $\begin{array}{c}\text { No idea } \\
\%\end{array}$ & $\begin{array}{c}\text { Total } \\
\%\end{array}$ \\
\hline Early marriage & 86.0 & 7.3 & 6.7 & 100.0 \\
\hline Negative perception of girls education & 73.3 & 22.7 & 4.0 & 100.0 \\
\hline Traditional ceremonies (unyago) & 68.7 & 21.4 & 10.0 & 100.0 \\
\hline Social roles & 67.3 & 25.4 & 7.3 & 100.0 \\
\hline Male preference & 67.4 & 26.0 & 6.7 & 100.0 \\
\hline
\end{tabular}

Source: Survey data

\subsection{Early Marriage}

The cultural practice of parents to arrange the early marriage for girl impacts on girls' access to education as agreed by $86 \%$ of respondents in Table 3. In many communities' cultures in Tanzania, parents arrange early and sometimes forced marriage for young girls. This can sometimes be encouraged by the contradictions 
of the laws of the country, as Law of Child Act of 2009 defines a child as a person under 18 years old, while a Law of Marriage Act of 1971 gives freedom to parents to marry a girl at the age of 15 years old. The early marriage cultural practice affects girls' education as many school girls drop out from school to get married as agreed by $76.7 \%$ of respondents as indicated in Table 4 . This result supported by other studies, Mtengeti et al. (2008) found that many girls forced by their parents, custodians or other members of the family to be married at an earlier age of 14 and 15 years old. Sometimes they are forced to quit the school to be married and are usually denied the chance to mature and make the decision for themselves over their lives before they are married. As a result, early marriage brings severe physical, psychological and emotional effects on married girls. Dowry payment mentioned as the main reason associating with child marriage in Tanzania (Human Rights Watch 2014). In many cultures in Tanzania, girls are primarily regarded as a source of wealth and thus can be married off sometimes by force at an early age instead of being sent to school, as the community perceive that early marriage brings quick returns than education (Gimbo et al. 2015). Systems of dowry and bride-price results to many negative influences on the participation of girls in education. The essential of paying a dowry may make a girl a burden to her parents, which together with any investment that may be made in her education frequently seen as a waste of inadequate resources. However, bride-price customs encourage early marriage whereby parents force their daughters to marry so that they can get wealth, sometimes girls forced to marry to gain money needed to find a wife for a son (Brock \& Nadine 1997).

Table 4: Responses of respondents on whether girls drop out from school to get married frequently.

\begin{tabular}{|l|c|}
\hline & Percent \\
\hline Agree & 76.7 \\
\hline Disagree & 16.7 \\
\hline No idea & \multicolumn{2}{|c|}{6.7} \\
\hline Total & 100.0 \\
\hline
\end{tabular}

Source: Survey data

\subsection{Social Perception}

Parents and community, in general, have the negative perception on girls' education as table 5 illustrates. Girls' education is perceived as meaningless for girls as they will be married and her education will benefit her husband's family as agreed by the majority $79.3 \%$ of respondents. Educating girls is also perceived as a waste of time and money as agreed by $70 \%$ of respondents, the community also believes that education makes girls be late married as $70.6 \%$ agreed. It also believed that 
education raises the pride price as $64 \%$ of respondents agreed on that. Moreover, some of the community members perceive that if a girl educated she will find difficulties to get the husband as $61.3 \%$ of respondents agreed. The negative perception placed on girls' education by the community affect girls' education as it leads to the low value of education hence parents prefer not to send their daughters to school as it will not have any profit to them rather than the loss. This lead parent to prefer their daughters being married at an early age rather than send them to school. DFID, (2005) and Shahidul (2015) argued that due to the perception that education reduces girls' marriage prospects since it raises dowry payments to unaffordable levels, thus resulting many girls to quit school sometimes by force from their parents. This result also concurs with the results of Scheuermann, (2013) and Amadi, (2013) studies which found that parents perceive girls education as wasted investment because education rises the marriage dowry while lessening the girls' knowledge of household chores they are supposed to do as wives. This lowers the reputation of educated girls in the society. Also, provision of education to girls' is perceived as a waste of resources since they married at an early age and moved into the husband's family. As a result, the family does not benefit from the returns on the financial investment in the education of the girl. All these bad perceptions interfere girls' education since the community negatively perceive girls education. In this case, it becomes difficult for the community to encourage and support their daughters to work hard on education rather than discourage them from abandoning education.

Table 5: Community perception on girls' education.

\begin{tabular}{|l|c|c|c|c|}
\hline Variable & $\begin{array}{c}\text { Agree } \\
\%\end{array}$ & $\begin{array}{c}\text { Disagree } \\
\%\end{array}$ & $\begin{array}{c}\text { No idea } \\
\%\end{array}$ & $\begin{array}{c}\text { Total } \\
\%\end{array}$ \\
\hline $\begin{array}{l}\text { Girls education will benefit her husband's } \\
\text { family }\end{array}$ & 79.3 & 15.4 & 5.3 & 100.0 \\
\hline Educating girls is a waste of time and money & 70.0 & 25.4 & 4.7 & 100.0 \\
\hline Education make girls late married & 70.6 & 21.4 & 8.0 & 100.0 \\
\hline Education raise bride price & 64.0 & 24.0 & 12.0 & 100.0 \\
\hline $\begin{array}{l}\text { Educated girls will find difficulties to get the } \\
\text { husband }\end{array}$ & 61.3 & 29.3 & 9.3 & 100.0 \\
\hline
\end{tabular}

Source: Survey data

\subsection{Traditional Ceremonies}

Unyago (which is considered as a local rite of passage, which girls undergo through it at an early stage of maturity, aims to introduce girls to social roles and sexually related roles as women in Mtwara) affects girls' education. Table 6 
indicates that girls who undergo unyago become rude to teachers as agreed by $56.7 \%$ of respondents. Also, the girls who undergo unyago isolate themselves from those who do not undergo unyago as agreed by $62.7 \%$ of respondents, likewise the girls who undergo unyago use vulgar language to those who do not undergo unyago as agreed by $57.3 \%$ of respondents. These ceremonies also increase absenteeism of girls in school as $60.7 \%$ of respondents agreed on it, moreover unyago increase girls' drop out of school as agreed by the majority $66.7 \%$ of respondents. In an informal discussion with teachers, they argue that after undergo unyago girls behaviors totally change in the manner that can affect their performance, and also it happens girls to become pregnant soon after unyago that lead to quitting school. Also in an informal interview with students, they argue that girls who undergo unyago feel that those who doesn't undergo are still young children though sometimes they are at the similar age hence tend to segregate them. The results of this study concur with other studies Ondiek, (2010), Kimonge, (2011)], Kainuwa \& Najeemah, (2013) found that girls who undergo initiation ceremonies considers themselves as adults and perceive school as an institution for children. As a result of this, they become rude to teachers, and often misbehave and become absenteeism in school hence perform badly in their studies and lead to drop out of school and opt to be married. Likewise, Helgesson, (2001) found that some girls lost their interest in schools soon after they pass through the initiation ceremony. They were introduced to another kind of life than they used to hence thoughts about boyfriends, beauty and marriage became more significant to them than studies. The initiation ceremony considerably based on sex, hence it encourages many girls to engage in sexual relationships immediately after undergoing through unyago ceremony.

Table 6: Traditional ceremonies (unyago) effects on girls' education

\begin{tabular}{|l|c|c|c|c|}
\hline Variable & $\begin{array}{c}\text { Agree } \\
\%\end{array}$ & $\begin{array}{c}\text { Disagree } \\
\%\end{array}$ & $\begin{array}{c}\text { No idea } \\
\%\end{array}$ & $\begin{array}{c}\text { Total } \\
\%\end{array}$ \\
\hline $\begin{array}{l}\text { Girls who undergo Unyago become rude to } \\
\text { teachers }\end{array}$ & 56.7 & 38.6 & 4.7 & 100.0 \\
\hline $\begin{array}{l}\text { Girls who undergo Unyago isolate themselves } \\
\text { from those who do not undergo Unyago }\end{array}$ & 62.7 & 30.0 & 7.3 & 100.0 \\
\hline $\begin{array}{l}\text { Girls who undergo Unyago use vulgar language } \\
\text { to those who do not undergo Unyago }\end{array}$ & 57.3 & 32.7 & 10.0 & 100.0 \\
\hline IncreaseS absenteeism of girls in school & 60.7 & 33.3 & 6.0 & 100.0 \\
\hline Increases girls' drop out from school & 66.7 & 29.3 & 4.0 & 100.0 \\
\hline
\end{tabular}

Source: Survey data 


\subsection{Social Roles}

Domestic chores hinder girl's academic achievement as girls are engaging in many activities as indicated in Table 7. Girls engage in domestic works whereby $76.8 \%$ of girls agreed to be involved in house cleanness, $72 \%$ engage in washing, $73.6 \%$ participate in cooking, 56\% participate in child caring. They also engage in academic activities $41.6 \%$ engage in self-study, $33.6 \%$ attending tuition, also $65.6 \%$ participate in farm works, and $63.2 \%$ engage in small business activities. The result reveals that girls have to engage in many activities that sometimes can affect their education. Though other girls agreed that they engage in self-study but this will still be affected by several activities they have to engage in, so they will not get enough time on their studies. Also, they may not be much active on studying due to tiredness, this can lead them to perform poorly in school, and only a few students have a chance to attend tuition. This implies that girls use their much time on domestic chores rather than on their studies. In an informal discussion with teachers, a teacher argues that most of the time girls use to sleep in class and after making a follow up it was realized that they use to help their parents to sell the small businesses at night like selling foods. The result of this study concurs with other studies as Juma \& Enosi, (2014) revealed that daughters are raised up for female roles such as child raising and domestic responsibilities as parents believe that females do not have qualities of independence, creativity, and confidence. These roles hinder girl student academic success as it reduces the girl's academic performance, especially in day schools, as well there are girl students that are asked by their parents to drop out of school and help them with household chores. Similarly, Amadi, (2013) and Mobar, (2015) discovered that girls are not sent to schools as they positioned in household chores. Ahmad et al. (2014) discussed that children at an early age of 7 years old are required to take part in different activities related to domestic responsibilities and farm activities before and after coming back from school and during weekend days. Especially in rural setting areas where children regarded as a source of labor for the family farms. Shel, (2007) recognized that heavy household workloads, domestic priorities, and gender roles mostly tend to undermine the girl and greatly hinder girls' progressions in education while creating a good environment for boys' education. The situation of favoring boys over girls has further negative consequences on girls in education. Whereby a chance of girl education is more limited especially if the girl is the first born in the family and having boys siblings. The girl needs to perform domestic chores while boys' siblings focus on school. Girls are fundamentally domestic workers to the benefit of their brothers (Hatlebakk 2012). The findings of this study that girls also engage in economic activities (small business) concur with the findings of Stephens, (2000) found that many girls are put at risk economically for minimum payments. Parents, especially fathers, are 
revoking their responsibilities in supporting their daughters, leaving the girls themselves to struggle for school and becoming the family breadwinner. The situation that negatively impacts the girl child education achievement by reducing her academic performance.

Table 7: Responses on social roles perform by girls before or after class hours

\begin{tabular}{|l|c|c|c|c|}
\hline Variable & Agree \% & Disagree \% & No idea \% & Total \% \\
\hline House cleanness & 76.8 & 21.6 & 1.6 & 100.0 \\
\hline Washing & 72.0 & 20.8 & 7.2 & 100.0 \\
\hline Cooking & 73.6 & 20.0 & 6.4 & 100.0 \\
\hline Self-study & 41.6 & 51.2 & 7.2 & 100.0 \\
\hline Child caring & 56.0 & 32.8 & 11.2 & 100.0 \\
\hline Farm Works & 65.6 & 24.8 & 9.6 & 100.0 \\
\hline Attend tuition & 33.6 & 59.2 & 7.2 & 100.0 \\
\hline Small businesses & 63.2 & 36.0 & .8 & 100.0 \\
\hline
\end{tabular}

Source: Survey data

\subsection{Male Preference}

The findings of this study have revealed that girls' education is not a priority within the community. Parents are preferred to educate boys than girls as the majority of respondents $70 \%$ agreed on that, as indicated in Table 8. In many cultures in Tanzania particularly in rural areas girls are not given priorities in many sections including priority to education. A severe problem that hinders girls and women's access and succeeds in education is the discrimination of women in the community. Some customs and traditions have been produced to block women from accessing economic independence that increases their vulnerability and becomes incapable of accessing education particularly for girls (GCE 2012). The only place that girls given priority are in household works and farm works. They are turned to be the family laborers who produce for the benefit of men. When it comes up on potential issues, only male given priority on it. Even if parents allow their girl child to attend the school, they are not willing to provide equal education support including moral and material assistance with sons because of some bad cultural beliefs that always tend to favor boys. Male preference have negative impacts on girls education as it lead parents to give main concern on boys education than girls education in different situations as revealed in Table 8 that when there is a hard economic condition in the family parents decide to educate their sons than daughters as agreed by $65.3 \%$ of respondents. Also $62.6 \%$ agreed that parents care about boy's education than girl's education. arent also prefer to make follow up on boys education than girls as agreed by $54.6 \%$ of respondent, $46.6 \%$ agreed that parents care about providing boys with school material than girls for example books; as 
well $50 \%$ of respondents agreed that parents provide school uniforms to boys than girls. The results reveal that parents are less involved in girls' education they most care about boys' education. The less involvement of parents in their girl child education can contribute to less achievement on girls' education. As Desarrollo, (2007) point out that the extent to which parents or other relatives are actively engaged in a student's education had a positive influence on the student's achievement. This results also concur with the studies of Hatlebakk, (2012) and UNICEF, (2004) found that if the family economy is not good to afford the cost of education for all children in the family, usually boys are given the priority than girls.

Table 8: Priorities of parents on supporting their children's education

\begin{tabular}{|l|c|c|c|c|}
\hline Variable & $\begin{array}{c}\text { Agree } \\
\%\end{array}$ & $\begin{array}{c}\text { Disagree } \\
\%\end{array}$ & $\begin{array}{c}\text { No idea } \\
\%\end{array}$ & $\begin{array}{c}\text { Total } \\
\%\end{array}$ \\
\hline $\begin{array}{l}\text { The community mostly prefer to educate boys } \\
\text { than girls }\end{array}$ & 70.0 & 26.6 & 3.3 & 100.0 \\
\hline $\begin{array}{l}\text { Parents provide school uniforms to boys than } \\
\text { girls }\end{array}$ & 50.0 & 44.0 & 6.0 & 100.0 \\
\hline $\begin{array}{l}\text { Parents care about providing boys with school } \\
\text { material e.g. books than girls }\end{array}$ & 46.6 & 44.0 & 9.3 & 100.0 \\
\hline $\begin{array}{l}\text { Parents make follow up on boys' academic } \\
\text { performance than on girls }\end{array}$ & 54.6 & 39.3 & 6.0 & 100.0 \\
\hline $\begin{array}{l}\text { Parents care about boys education than girls } \\
\text { education }\end{array}$ & 62.6 & 30.0 & 7.3 & 100.0 \\
\hline $\begin{array}{l}\text { In hard economic condition within the family, } \\
\text { parents prefer to educate boys than girls }\end{array}$ & 65.3 & 29.3 & 5.3 & 100.0 \\
\hline
\end{tabular}

Source: Survey data

\section{Conclusion}

Socio-cultural factors are largely affecting girls' access to education. Early marriage, traditional ceremonies (unyago), male preference, social perception and social roles are among the key socio-cultural factors hinder girls education in Mtwara District in Tanzania. The government and other education stakeholders should sensitize the community on the need and significance of girls' education for girls themselves and the community in general. Education stakeholders also should launch mass media programs like television and radio programs to educate and discourage the bad socio-cultural practices in the community that deteriorate girls' education. To formulate and strengthen child protection team within the community from the village level to the district level. This will help to expose the issues concerning children that happen in the community and sometimes be hidden by the community, like causing pregnant to students, early and forced marriage. The government should take the serious action for those who participate in one 
way or another in declining girl's education. The government should modify the laws to avoid the contradictions and ensure that the laws are based on the best interest of the child regardless of their gender. The community should be advised not to put the initiation ceremonies such as unyago in a very sexual manner since most of the time the intended group for these ceremonies is at an early age. The finding of this study contributes to the advancement of knowledge about the negative effects of bad cultural practices to girls' education. The study is also useful in informing the education stakeholders including policy makers, planners, government, non-government organizations about key socio-cultural constraints to girls' education. This will sensitize the stakeholders to fight or find the way to eradicate the problem and pave the smooth way to girls' education. These findings may be used by the education stakeholders in laying down a foundation that will possibly be used in improving the situation of girls' education.

\section{Acknowledgment}

I would like to give my appreciations to my supervisor's and Chinese Scholarship Council (CSC). I extend my deepest appreciation to my husband Idfonce Ernest and our daughter Noreen and my parents for their support and encouragement during the entire duration I was undertaking my studies at University of Science and Technology of China (USTC).

\section{References and notes:}

Ahmad. I, Hamdan. S, Altaf. H and Sadaf. K. (2014). "Barriers to Co-Education in Pakistan and its Implication on Girls Education: Critical Review of Literature." Sci.Int (Lahore),26(1),339 -345,2014.

Amadi. E. C. (2013). "Socio-Cultural Factors on the Girls-Child Education in Secondary School in Ihiala Local Government Area of Anambra State, Nigeria." International Journal of Education Learning and Development Vol.1, No.1, pp. 71-74.

Anisur.R.Kh.(2015)."Domestic Violence against Women in Bangladesh:A Review of the Literature and the Gaps to fill-in by Future Interventions".Khazar Journal of Humanities and Social Sciences. Azerbaijan. Vol 18,No.3,pp.57-81.

Batho. P. (2012). "Assessing the Relationship between teenage pregnancy and unyago and education level: A case of Mtwara Region in Tanzania." SEGi Review Vol.5, (No. 2): 27-35.

Brock. C, and Nadine. C. (1997). "Factors affecting female participation in education in seven developingcountries" Education Research Paper No. 09 (96 p.). 
Desarrollo. I. (2007). "The Quality of Education in Latin America and Caribbean Latin America:." Research Work Institute Desarrollo: Paraguay.

DFID. (2005). "Girls'education: towards a better future for all." Published by the Department for International Development.

DFID. (2006). "DFID's girls' education strategy Girls' education: towards a better future for all. First progress report."

GCE. (2012). "Gender Discrimination in Education: The violation of rights of women and girls." Global Campaign for Education. Johannesburg.

Gibson. S. (2004). "Girls' Education in Africa: An Overview of what works." The IDLgroup.

Gimbo R, Nadine M, and Sara S. (2015). "Why Maasai Parents Enroll their Children in Primary School: The Case of Makuyuni in Northern Tanzania." Interdisciplinary Journal of Best Practices in Global Development Volume 1, Article 5.

Hatlebakk. M. (2012). "Son preference, the number of children, education and occupational choice in rural Nepal." CMI Working Paper WP 2012: 8.

Helgesson. L. (2001). "(E) Quality: Girls' and Boys' Basic Education in Masasi and Kisarawe Districts. Research Report by a Joint Team from Ministry of Education and Culture, Kuleana Centre for Children's Rights and UNICEF Tanzania Dar es Salaam, pg 49 - 50.".

Human, Rights Watch. (2014). "No Way Out: Child Marriage and Human Rights Abuses in Tanzania." Human Rights Watch.

Juma. L. S. A, and Enosi M. W .S. (2014). "Impact of Cultural Factors on Girl Students' Academic Achievement in Secondary Schools in Kenya: A Case Study of Kisumu East District." Educational Research Journal 5 (5). doi: 10.14303/er.2014.094.

Kainuwa. A, and Najeemah. M. Y. (2013). "Cultural Traditions and Practices of the Parents as Barriers to Girl-child Education in Zamfara State Nigeria." International Journal of Scientific and Research Publications Volume 3 ( Issue 11).

Katie. M, and Unterhalter. E. 2015. "Empowering women and girls through education." European Parliament.

Kessler. C. (2009). "PASHA's Contribution to Addressing Teenage Pregnancies in Tanzanian Schools." Swiss Centre for International Health, Switzerland.

Kimonge. B. M. H. (2011). "Impact of female genital mutilation on the education of girls with hearing impairment in Gucha County-Kenya." A thesis submitted in partial fulfillment for the degree of master of education (special education) in the school of Education, Kenyatta University.

Mobar. S. (2015). "Impact of RTE Act on Girl Child Education." International Journal of Social Science and Humanity 5 (10):903-906. doi: 10.7763/ijssh.2015.v5.577.

Mtengeti. K, Emmanuel. J, Juliana. M, Albert. W, and Grace. M. (2008). "Report on ChildMarriage Survey Conducted in Dar es Salaam, Coastal, Mwanza and Mara Regions." Children's Dignity Forum(CDF).

Ondiek. C. A. (2010). "The persistence of female genital mutilation (FGM) and its impact on women's access to education and empowerment: A study of Kuria District, Nyanza Province, Kenya." A dissertation submitted in fulfillment of the requirements for the degree of doctor of literature and philosophy. 
Sasford. R. (2007). "Survey Research (2nd Edition). ." London: Sage Publishers Limited.

Scheuermann. A. 2013. "Barriers to Equity in Education: An Exploratory Case Study on Nepal." Student Paper Series MPP.

Shahidul. S. M, and Zehadul K. A. H. M. (2015). "Factors Contributing to School Dropout among the Girls: A Review of Literature." European Journal of Research and Reflection in Educational Sciences Vol. 3 No. 2.

Shel. T. A. (2007). "Background paper prepared for the Education for All Global Monitoring Report 2008 Education for All by 2015: will we make it? Gender and Inequity in Education. Literature Review." UNESCO 2008/ED/EFA/MRT/PI/67.

Stephens. D. (2000). "Girls and basic education in Ghana: a cultural enquiry." International Journal of Educational Development 20 29-47.

Temba. E, Leticia. W, and Msabila. D. (2013). "Assessing Efforts to Address Cultural Constraints to Girls' Access to Education Among the Maasai in Tanzania: A Case Study of Monduli District." Journal of International Cooperation in Education Vol.15 No.3 pp.21 37.

UNESCO. (2011). "Tanzania Education Sector Analysis. Beyond Primary Education, the Quest for Balanced and Efficient Policy Choices for Human Development and Economic Growth." Regional Bureau for Education in Africa.

UNESCO. (2014). "Teaching and Learning: Achieving quality for all Gender Summary." EFA Global Monitoring Report 204 (3/4).

UNICEF. 2004. "Strategies for Girls' Education." The United Nations Children's Fund (UNICEF), New York.

UNICEF. (2007). "Empowerment Through Girls' Education." The catalyst for Education and Gender Equality (1).

URT. (2005). "The Constitution of the United Republic of Tanzania of 1977. Chapter 2 of the Laws.".

USAID. (2013). "Tanzania Education Strategy for Improving the Quality of Education."

Zombwe. G, Vira. N, and Jeremia. S. (2010). "How to Ensure Educational Success for Girls. They have the right to complete their studies." HakiElimu Position Paper 2010E. 


\title{
Summary
}

\section{Socio-cultural Constraints of Girls' Access to Education in Mtwara District, Tanzania}

\author{
Neema Silas Mollel \\ University of Science and Technology of China (USTC), China \\ Ren Chong \\ University of Science and Technology of China (USTC),China
}

Girls are in a detrimental situation concerning accessing and succeeding in their formal education. Repetition and dropout proportion are significantly higher to girls while completion rate is very low. Also, there is a substantial gender inequality in providing education and performance in education between girls and boys. This research aimed to examine the socio-cultural factors that hinder girls' education in Mtwara District in Tanzania. The design that adopted in this research is survey research design. The questionnaire used as a tool to gather the infor $\neg$ mation, also documentary review and data from Mtwara District Education Office about girls' enrolment and completion used as secondary data. The data organized and then analyzed with the use of the computer. IBM SPSS software used. Descrip-tive statistics used to analyze the data. The findings of this study discovered that socio-cultural factors mostly affecting girls' access to education. Early marriage, traditional ceremonies (unyago), social perception and social roles are among the key socio-cultural factors hinder girls education in Mtwara District. The study concluded that socio-cultural factors are mostly affecting girls' access to education in Mtwara District in Tanzania. The study suggested that the government and other education stakeholders should sensitize the community on the need and significance of girls' education for girls themselves and to the entire community. Education stakeholders also should launch mass media programs like television and radio programs to educate and discourage the bad sociocultural practices within the community that deteriorate girls' education. The government should take the serious action for those who participate in one way or another in declining girls' education.

Keywords: Socio-cultural, Constraints, Girl, Education, Mtwara, Tanzania. 